Acta Theriologica 42 (2): 203-224, 1997.

PL ISSN 0001-7051

\title{
Predation of Eurasian lynx on roe deer and red deer in Białowieża Primeval Forest, Poland
}

\author{
Henryk OKARMA, Włodzimierz JĘDRZEJEWSKI, Krzysztof SCHMIDT, \\ Rafał KOWALCZYK and Bogumiła JĘDRZEJEWSKA*
}

\begin{abstract}
Okarma H., Jędrzejewski W., Schmidt K., Kowalczyk R. and Jędrzejewska B. 1997. Predation of Eurasian lynx on roe deer and red deer in Białowieża Primeval Forest, Poland. Acta Theriologica 42: 203-224.
\end{abstract}

Patterns of lynx Lynx lynx (Linnaeus, 1758) predation on ungulates were studied in the Polish part of Bialowieża Primeval Forest $\left(580 \mathrm{~km}^{2}\right)$ from scats and prey remains of lynx between 1985-1996, and radiotracking of 18 lynx between 1991-1996. Cervids were the main prey and constituted $90 \%$ of food biomass consumed (analysis of faeces) and $84 \%$ of prey killed. Roe deer Capreolus capreolus was positively selected by all lynx (though stronger by females and subadults than by adult males). Fawns and adult roe deer of both sexes were preyed on in proportion to their abundance in the population. Red deer Cervus elaphus was taken less often than would have been expected at random, and fawns were positively selected by lynx. On average, lynx spent $76 \mathrm{~h}$ ( 3.2 days) feeding on a killed deer (from $38 \mathrm{~h}$ in a female with 3 kittens to $105 \mathrm{~h}$ in single adult females). Mean searching time (ie time from leaving the remains of one deer to killing another one) was $52 \mathrm{~h}(2.2$ days $)$; from $10 \mathrm{~h}$ in a female with 3 young to $104 \mathrm{~h}$ in subadults. Thus, the average kill rate by lynx was one deer per 5.4 days. Predation impact of lynx population on roe and red deer was estimated in 1991-1996, when recorded numbers were 288-492 roe deer and 359-607 red deer per $100 \mathrm{~km}^{2}$ in late winter (March), and 501-820 roe deer and 514-858 red deer per $100 \mathrm{~km}^{2}$ in spring (May/June). During that period densities of deer declined markedly due to deliberately elevated hunting harvest by forestry personnel, aimed at reduction of game damage to silviculture. Densities of adult lynx were little variable (2.4-3.2 inds $/ 100 \mathrm{~km}^{2}$ ), but reproduction rate strongly varied in response to deer decline, from 0.67 juv/adult lynx in $1991 / 92$ to 0.25 juv/adult lynx in $1995 / 96$. Annually, lynx population killed $110-169$ roe deer $/ 100 \mathrm{~km}^{2}$, which constituted $21-36 \%$ of spring (seasonally highest) numbers of roe deer. Lynx predation was the most important factor of roe deer mortality. Furthermore, lynx population took 42-70 red deer/100 $\mathrm{km}^{2}$ annually, which constituted $6-13 \%$ of spring number of red deer. In red deer mortality, lynx predation played an inferior role to hunting harvest and wolf predation.

Mammal Research Institute, Polish Academy of Sciences, 17-230 Białowieża, Poland (HO, WJ, KS, RK); Workshop for Ecology and Protection of the Natural Environment, 17-230 Białowieża, Poland (BJ)

Key words: Lynx lynx, Capreolus capreolus, Cervus elaphus, kill rate, ungulates, prey selection

*Present address: Mammal Research Institute, Polish Academy of Sciences, 17-230 Białowieża, Poland 


\section{Introduction}

In the field of large predator-ungulate relationships in the Holarctic zone, most contemporary knowledge comes from North American studies on wolves Canis lupus, moose Alces alces, white-tailed deer Odocoileus virginianus, and caribou Rangifer tarandus. Most researchers that studied North American large predators (wolves and/or bear) reported on their limiting effect on ungulates (eg Seip 1992, Van Ballenberghe and Ballard 1994). In his recent reviews and syntheses, Messier (1994, 1995) came to the conclusion that wolf predation appeared density-dependent at the lowest range of moose densities, but it was inversely density-dependent at higher densities.

The relationship between ungulates and large predators in the Palearctic may differ markedly from those in the Nearctic region, due to higher richness of both ungulate and predator communities in Eurasia. For instance, in the forests of Europe, up to five coexisting species of ungulates are subject to predation by (most typically) three large carnivores (eg Okarma 1995, Okarma et al. 1995), to say nothing of the temperate forests in the Russian Far East (eg Sikhote-Alin Reserve), where seven large carnivores coexist with seven species of ungulates (Rakov 1979). A diverse spectrum of potential prey most likely affects both functional and numerical responses by predators, and - in consequence - the total predation rates.

Eurasian lynx Lynx lynx (Linnaeus, 1758) is an interesting species for studying predation. In Europe, ungulates replace hare in lynx diet along the North-South gradient. In temperate forests ungulates, particularly the roe deer Capreolus capreolus, constitute the bulk of lynx prey (Jędrzejewski et al. 1993). Furthermore, in large forest tracts of central and eastern Europe, lynx was reported to attain densities up to 6 individuals per $100 \mathrm{~km}^{2}$ (Zheltukhin 1986, Jędrzejewski et al. 1996). Consequent upon these facts can be the high and significant predation by lynx on cervids. Indirect evidence for this was provided by Gaross (1979), who compared roe deer densities in 107 randomly selected forest administration units in Latvia. He found, on average, 7.8 roe deer $/ \mathrm{km}^{2}$ in forests where neither lynx nor wolf occurred, compared to $2.8 \mathrm{deer} / \mathrm{km}^{2}$ in forests with lynx populations.

In this paper we present the results of our long-term study on predation by the Eurasian lynx on ungulates in the deciduous and mixed forests in Eastern Poland. We aimed at showing: (1) the mechanisms of prey selection and functional response of lynx to varying availability of roe deer and red deer Cervus elaphus; (2) rates of killing and consumption of deer by radio-collared lynx; and (3) lynx predation on deer in relation to their density. Finally, we discussed the mechanisms and sources of variation in lynx predation on ungulates in the pristine forests of Europe. 


\section{Study area}

Białowieża Primeval Forest (BPF) of $1,250 \mathrm{~km}^{2}$ is the best preserved woodland of its size in lowland temperate Europe. It is located on the Polish-Belarussian border. Tree stands of BPF are dominated by oak Quercus robur, hornbeam Carpinus betulus, black alder Alnus glutinosa, spruce Picea abies, and pine Pinus silvestris. Detailed information on vegetation is given by Faliński (1986). The Polish part of BPF, where this study was conducted $\left(580 \mathrm{~km}^{2}\right)$, consists of exploited $\left(530 \mathrm{~km}^{2}\right)$ and strictly protected $\left(47 \mathrm{~km}^{2}\right)$ parts. The exploited forests (average age 72 years) undergo timber harvest, reforestation, and game hunting. In the protected part (Białowieża National Park = BNP), most of the tree stands (average age 130 years) are of natural origin. Neither exploitation of timber nor game hunting is allowed in the BNP.

BPF harbours a rich community of ungulates: European bison Bison bonasus, moose, red deer, roe deer, and wild boar Sus scrofa (Jędrzejewska et al. 1994). The bison is a protected species, and its population size is kept stable by yearly culling. The four other species of ungulates are hunted in the exploited part of BPF. The pristine guild of large carnivores was impoverished in the 19th century by extermination of brown bear Ursus arctos and currently it contains two species, the wolf and the lynx. During the last 150 years, numbers of wolf and lynx ranged from near 0 (after prolonged predator control) to very high (Jędrzejewska et al. 1996, Jędrzejewski et al. 1996).

\section{Material and methods}

\section{Analysis of lynx prey and diet composition}

Between 1985-1996, a total of 139 lynx scats was collected and analysed according to the procedure described by Jędrzejewski et al. (1993). Prey were identified by bone, hair, and feather remains, and the relative shares of various prey were presented as percentage occurrence in the total sample of scats, and percentage of biomass consumed by lynx (see Jędrzejewski et al. 1993 for details). Between 1987-1996, a total of 172 prey remains was found during snowtracking and radiotracking of lynx. In the case of roe deer and red deer carcasses, the age (according to the tooth wear, after Lochman 1987 and Pielowski 1988) and sex were identified whenever possible. The bones of one hind leg were removed from deer carcasses for marrow analysis. Marrow samples of 20-30 grams were taken from the middle part of the femur, tibia, and metatarsus. Percentage of fat in bone marrow was estimated on the basis of dry-weight method (Neiland 1970), which had already been tested for roe deer (Ratcliffe 1980) and red deer (Okarma 1989).

\section{Estimating of lynx predation impact on ungulates}

Between 1991-1996, eighteen lynx were livetrapped and radiocollared (see Jędrzejewski et al. 1996). The bulk of data presented in this paper comes from 11 individuals that were radiotracked for $>1$ year. Radiotracking was conducted 5 to 7 days a week. In addition to daily locations, a continuous 5-day radiotracking session of a selected lynx was conducted once a month in 1994-1995, and less regularly (1-5 days) in 1991-1993. During continuous tracking sessions, five persons worked in 8 -hour shifts. A person followed the lynx within a distance of $0.5-1 \mathrm{~km}$. To find lynx kills, each time the lynx stayed in one place for at least several hours we tried to locate it precisely by taking two bearings from perpendicular roads nearest to the lynx or by quiet approaching it to a distance of about 150-200 m (but not closer in order not to disturb it). Such precise localisations were done at the time when we expected the lynx to be feeding on a prey (ie from dusk till late evening). Some lynxes were equipped with radiocollars with an activity switch, which made the time of feeding recognizable. After the lynx had left the spot, we searched that place carefully for prey remains. We succeeded in about $50 \%$ of our searching attempts. 
If we were successful in finding one or more prey during a continuous 5-day tracking, we extended the closer observations of the same lynx by localising it at least twice daily (during a day and at night) for several days (up to one month). All locations where a lynx was localized repeatedly were searched. If a lynx stayed in the same place for a relatively short time (less than two days) and we did not find any prey remains, we assumed that lynx did not have any larger prey (an ungulate). If the lynx stayed longer in the same spot and we failed to find its prey, we assumed that the lynx actually killed an ungulate but we were unsuccessful in finding it.

For each ungulate prey found during continuous radiotracking sessions, we calculated the time of its consumption by lynx ( $T_{\mathrm{C}}$, in hours). For all series of consecutively killed prey (when two or more consecutive prey were found), we calculated the searching time by a lynx ( $T_{\mathrm{S}}$, in hours), ie the time span from leaving an ungulate carcass to killing another ungulate. We also measured the straight-line distance between consecutive kills.

The killing rate $(K)$, ie the number of roe deer and red deer killed by a Iynx per month was calculated according to the following formulas:

and

$$
K_{\text {roe }}=720 R /\left[R\left(T_{\text {Croe }}+T_{\mathrm{S}}\right)+\left(T_{\text {Cred }}+T_{\mathrm{S}}\right)\right]
$$

$$
K_{\text {red }}=720 /\left[R\left(T_{\text {Croe }}+T_{\mathrm{S}}\right)+\left(T_{\text {Cred }}+T_{\mathrm{S}}\right)\right]
$$

where: $K_{\text {roe }}$ and $K_{\text {red }}$ - numbers of roe deer and red deer, respectively, killed by a lynx per month; $T_{\text {Croe }}$ and $T_{\text {Cred }}$ - mean consumption times of, respectively, roe deer and red deer by a lynx (in hours); $T_{\mathrm{S}}-$ mean time of searching for ungulate prey by a lynx; $R$-ratio of roe deer to red deer number among prey found for a given age/sex class of lynx; $720=$ number of hours in one month.

Killing rates of roe and red deer were calculated for three classes of lynx: (1) adult males, (2) adult females with kittens, and (3) subadults of both sexes and single adult females. For calculation of total predation by Iynx population (in 1991-1996), we used lynx densities and population structure estimated by year round radiotracking and winter snowtracking. Methods and full data for 1991/92-1993/94 are presented by Jędrzejewski et al. (1996).

\section{Parameters of ungulate populations}

In late winter (February or March) of 1991, 1992, and 1993, game wardens of Białowieża, Browsk and Hajnówka Forest Administration units conducted surveys of ungulates (under the supervision of L. Miłkowski) on 26-50 randomly selected forest compartments (about $1.14 \mathrm{~km}^{2}$ each). Of nine game hunting districts located in the exploited forests of BPF, the surveys sampled from 6 (in 1992) to 9 districts (in 1991). In late winter of 1991 and 1992, we conducted censuses of ungulates on $11.2-\mathrm{km}^{2}$ area in Białowieża National Park. In all cases, ungulates were surveyed by driving censuses (Hazzard 1958). Each forest compartment or block of adjoining compartments to be surveyed was surrounded by observers standing at 50-100 m intervals (to keep visual contact). The observers along three sides of a censused area remained stationary, while those along the fourth side moved inward quietly and went through the entire area as a battue line. All observers noted the ungulates passing through the lines of observers (on their right-hand side only) and into the closed area being censused. Moreover, age and sex of deer (fawn, adult female or adult male) were identified whenever possible. The census yielded the absolute numbers of ungulates, calculated as the difference between the number of ungulates seen to leave a census section and those observed to enter it. Totally, the driving censuses covered from $40.2 \mathrm{~km}^{2}$ in 1992 to $66.5 \mathrm{~km}^{2}$ in 1991 , ie $7.0-11.5 \%$ of the whole Polish part of BPF. When calculating the mean densities of deer in the whole Forest, we corrected for uncensused parts of the Forest ( 3 game hunting districts in 1992, one game district and BNP in 1993), based on relative abundance of deer in those districts in the years with data available. More detailed description and presentation of data from 1991 are found in Jędrzejewska et al. (1994).

Furthermore, information on deer densities in late winter 1995 was provided by Kossak (1995), who conducted a drive census on a total of $51.5 \mathrm{~km}^{2}$ in all game districts in the exploited forests of $\mathrm{BPF}$. However, these results are not fully comparable to earlier data because forest compartments 
were not selected randomly but formed a regular net. This resulted in substantial overrepresentation of deciduous forests in the total sample, and might have overestimated (as compared to earlier years) the number of ungulates. Estimates by Kossak (1995) were also corrected for the uncensused area of BNP. Since census in 1995 yielded unreliable measures of age/sex structure of deer, we have used respective figures from a sample of culled deer reported by Kossak (1995).

To calculate late spring/early summer numbers of deer, we applied the reproductive parameters of roe deer after Sablina (1955), who found that in the early summers of $1946-1948$, on average 95\% adult females were leading fawns (mean 1.52 juv./mother, thus 1.45 juv./adult female). In red deer, we used own visual observations collected in BPF between 1987-1995. In a total of 276 adult females with young (only observations with unambiguously determined sex/age of individuals), the mean number of fawns per adult female was 0.9 in July and declined steadily to 0.58 in January-February and 0.35 in March-April. This conforms to the data obtained by drive censuses; in late winters of 1991-1993, 0.43 to 0.59 juveniles per adult female red deer were recorded. Data on annual hunting harvest of deer were kindly provided by the Forest Administration offices of Bialowieża, Browsk and Hajnówka, and by the Regional Headquarters of State Forests in Białystok.

Two sources of information on the spatial variation of roe and red deer numbers in BPF were used. The first was the results of driving census done in 1991 (see Jędrzejewska et al. 1994 for cartographic presentation of data). Secondly, we mapped all visual observations of deer ( $N=527$ individuals) recorded during the field work between 1991-1995. These observations reliably represented the relative proportions of roe and red deer numbers; in the areas of game hunting districts and BNP, the percentages of roe deer among all observed deer correlated with those obtained by driving census in 1991 ( $r=0.96, p<0.0005, n=9$ districts with available data).

\section{Results}

Diet composition and prey selection by lynx

Roe deer and red deer were the staple food of lynx in Białowieża Primeval Forest; deer constituted $93.8 \%$ of biomass consumed in spring-summer and $89.9 \%$ in autum-winter (Table 1). Sporadically, wild boar fell as prey to lynx. Of small-sized prey found in lynx scats, only the brown hare had some importance ( $6 \%$ of biomass consumed in autumn-winter). A similar picture of lynx diet emerged from the analysis of 172 prey remains found on trails of radiotracked and snowtracked lynx; in both spring-summer and autumn-winter seasons, $85 \%$ of kills were ungulates, predominantly roe deer $(62 \%)$ and red deer $(22 \%)$. Brown hare made $9 \%$ of prey found (Table 2). While roe deer was the most common prey of all lynx sex/age classes (59-69\%; Table 2), the shares of large and small-sized prey varied. Adult male lynx captured significantly more red $\operatorname{deer}(G=19.8, \mathrm{df}=2$, $p<0.001)$ and fewer small-sized prey $(G=23.7, \mathrm{df}=2, p<0.001)$ than adult female lynx with kittens and subadults (Table 2). Brown hare was hunted more often by subadults and single adult females ( $19 \%$ of their prey) than by other lynx ( $G=16.1, \mathrm{df}=2, p<0.001$ ). Finally, family groups (females with kittens) captured other small-sized prey (birds and mammals) in quantities significantly exceeding that found on trails of single lynx $(G=17.1, \mathrm{df}=2, p<0.001)$. Tracks on snow indicated that, in two cases at least, the small prey (a marten and a hare) were captured by the kittens. 
Table 1. Diet composition of lynx in the Białowieża Primeval Forest in spring-summer (16 April - 30 September) and autumn-winter (1 October - 15 April) of 1985/86-1995. $n$ - number of scats. \% Occ - percentage occurrence in scats, \% Bio - percentage of total biomass consumed by lynx.

\begin{tabular}{|c|c|c|c|c|}
\hline \multirow[t]{2}{*}{ Item } & \multicolumn{2}{|c|}{$\begin{array}{l}\text { Spring-summer } \\
\quad(n=12)\end{array}$} & \multicolumn{2}{|c|}{$\begin{array}{l}\text { Autumn-winter } \\
\quad(n=127)\end{array}$} \\
\hline & $\%$ Occ & $\%$ Bio & $\%$ Occ & $\%$ Bio \\
\hline Roe deer Capreolus capreolus & 8.3 & 16.4 & 8.7 & 9.6 \\
\hline Red deer Cervus elaphus & - & - & 5.5 & 10.9 \\
\hline Undetermined Cervidae & 75.0 & 77.4 & 74.0 & 69.4 \\
\hline Cervidae total & 83.3 & 93.8 & 87.4 & 89.9 \\
\hline Wild boar Sus scrofa & - & - & 3.9 & 1.0 \\
\hline Brown hare Lepus europaeus & 16.7 & 1.0 & 11.0 & 6.0 \\
\hline Pine marten Martes martes & - & - & 0.8 & 2.3 \\
\hline Raccoon dog Nyctereutes procyonoides & - & - & 1.6 & 0.1 \\
\hline Domestic dog Canis familiaris & 8.3 & 3.4 & 0.8 & + \\
\hline Red squirrel Sciurus vulgaris & - & - & 0.8 & + \\
\hline Voles Microtus spp. & 8.3 & 0.1 & 0.8 & + \\
\hline Bank vole Clethrionomys glareolus & - & - & 0.8 & + \\
\hline Pine vole Pitymys subterraneus & - & - & 0.8 & 0.1 \\
\hline Shrews Soricidae & - & - & 0.8 & + \\
\hline Micromammalia total & 8.3 & 0.1 & 0.8 & + \\
\hline Undetermined thrush Turdus spp. & 8.3 & 1.3 & - & - \\
\hline Undetermined owl Strigidae & - & - & 0.8 & + \\
\hline Hazel hen Tetrastes bonasia & - & - & 1.6 & 0.1 \\
\hline Domestic hen Gallus domesticus & - & - & 0.8 & 0.3 \\
\hline Undetermined bird & - & - & 0.8 & + \\
\hline Birds total & 8.3 & 1.3 & 3.9 & 0.5 \\
\hline Amphibians & - & - & 0.8 & + \\
\hline Insects & - & - & 0.8 & + \\
\hline Plant material & 16.7 & 0.4 & 12.6 & 0.1 \\
\hline Biomass consumed per 1 scat (g) & & 1591 & & 529 \\
\hline
\end{tabular}

Lynx preyed on adult and fawn roe deer roughly in proportion to their abundance in the living population $(G=1.124 \mathrm{df}=2, p>0.5$; Table 3). Among 75 roe deer killed by lynx, fawns comprised $33 \%$, and older classes were represented by still decreasing proportions (Fig. 1). The oldest roe deer killed by lynx was $>9$ years old. No such detailed data on the age structure of the local living population of roe deer is available. It seems, nonetheless, that lynx does not select for any age class of roe deer. By contrast, when hunting for red deer, the lynx were highly selective $(G=48.5, \mathrm{df}=2, p<0.001)$; they killed predominantly fawns and no adult males (Table 3 ). From the femur marrow fat content in 70 roe 
Table 2. Species composition of lynx kills in numbers (and percentages) found during radiotracking and snowtracking between 1987-1996 in Białowieża Primeval Forest. Sp-Su - spring-summer, Au-Wi - autumn-winter, M - male, F - female, ad - adult. Mean body masses of lynx were: adult male $21.2 \mathrm{~kg}$, adult female $15.7 \mathrm{~kg}$, subadult $15 \mathrm{~kg}$, kitten $9 \mathrm{~kg}$ (data for autumn-winter season, Jędrzejewski et al. 1996). ${ }^{\mathrm{a}}$ Asio otus, ${ }^{\mathrm{b}}$ Dendrocopos major.

\begin{tabular}{|c|c|c|c|c|c|c|c|}
\hline \multirow[b]{2}{*}{ Prey species } & \multicolumn{4}{|c|}{ Prey of lynx of a given sex/age class } & \multicolumn{3}{|c|}{ Total prey found } \\
\hline & Ad M & $\begin{array}{l}\text { Ad F with } \\
\text { kittens }\end{array}$ & $\begin{array}{c}\text { Subadults } \\
\text { and single } \\
\text { ad F }\end{array}$ & $\begin{array}{c}\text { Unknown } \\
\text { single } \\
\text { lynx }\end{array}$ & $\mathrm{Sp}-\mathrm{Su}$ & $\mathrm{Au}-\mathrm{Wi}$ & $\begin{array}{l}\text { Sum } \\
n(\%)\end{array}$ \\
\hline Wild boar & $2(3 \%)$ & - & - & - & - & 2 & $2(1 \%)$ \\
\hline Red deer & $22(36 \%)$ & $10(18 \%)$ & $4(8 \%)$ & 2 & 6 & 32 & $38(22 \%)$ \\
\hline Roe deer & $36(59 \%)$ & $34(61 \%)$ & $34(69 \%)$ & 2 & 34 & 72 & $106(62 \%)$ \\
\hline Brown hare & $1(2 \%)$ & $5(9 \%)$ & $9(19 \%)$ & - & 5 & 10 & $15(9 \%)$ \\
\hline Domestic dog & - & - & $1(2 \%)$ & - & - & 1 & $1(0.5 \%)$ \\
\hline Pine marten & - & $2(3 \%)$ & - & - & 1 & 1 & $2(1 \%)$ \\
\hline Red squirrel & - & - & - & 1 & - & 1 & $1(0.5 \%)$ \\
\hline Hazel hen & - & $1(2 \%)$ & $1(2 \%)$ & 1 & 1 & 2 & $3(2 \%)$ \\
\hline Long-eared owl ${ }^{\mathrm{a}}$ & - & $1(2 \%)$ & - & - & - & 1 & $1(0.5 \%)$ \\
\hline Thrush & - & $2(3 \%)$ & - & - & - & 2 & $2(1 \%)$ \\
\hline Great spotted woodpecker ${ }^{b}$ & - & $1(2 \%)$ & - & - & - & 1 & $1(0.5 \%)$ \\
\hline Total $n(\%)$ & $61(100 \%)$ & $56(100 \%)$ & $49(100 \%)$ & 6 & 47 & 125 & $172(100 \%)$ \\
\hline
\end{tabular}

Table 3. Selection of sex/age classes of roe deer and red deer killed by lynx in 1987/88-1996. Percentages of age/sex classes of deer killed by lynx compared to their mean percentages in the living populations in late winter (March), ${ }^{* * *} p<0.001$ ( $G$-test for homogeneity of percentages; composition of lynx prey compared with living population of deer).

\begin{tabular}{|c|c|c|c|c|c|c|}
\hline \multirow{3}{*}{ Sample } & \multicolumn{6}{|c|}{ Age/sex class of deer } \\
\hline & \multicolumn{2}{|c|}{ Adult males } & \multicolumn{2}{|c|}{ Adult females } & \multicolumn{2}{|c|}{ Juveniles } \\
\hline & $n$ & $\%$ & $n$ & $\%$ & $n$ & $\%$ \\
\hline \multicolumn{7}{|c|}{ Roe deer } \\
\hline Lynx prey in spring-summer & 8 & 29 & 11 & 39 & 9 & 32 \\
\hline Lynx prey in autumn-winter & 13 & 20 & 27 & 42 & 24 & 38 \\
\hline Total lynx prey & 21 & 23 & 38 & 41 & 33 & 36 \\
\hline Living population of roe deer (March) & & 25 & & 46 & & 29 \\
\hline \multicolumn{7}{|c|}{ Red deer } \\
\hline Lynx prey in spring-summer & - & & 1 & & 5 & \\
\hline Lynx prey in autumn-winter & - & 0 & 13 & 43 & 17 & 57 \\
\hline Total lynx prey & - & $0^{* * *}$ & 14 & 39 & 22 & $61^{* * * *}$ \\
\hline Living population of red deer (March) & & 27 & & 46 & & 27 \\
\hline
\end{tabular}




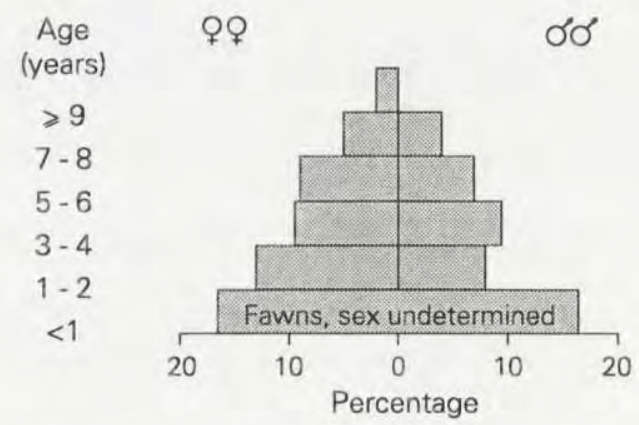

Fig. 1. Age (as determined by tooth wear) and sex structure of roe deer $(n=75)$ killed by lynx in BPF in $1987 / 88-1996$.

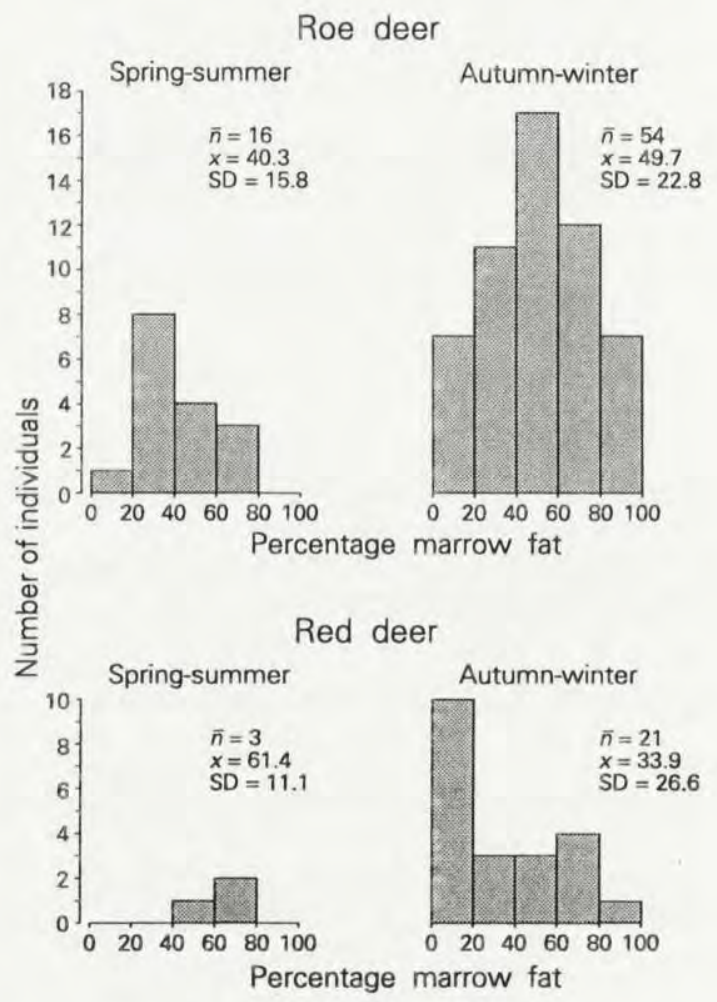

Fig. 2. Frequency distributions and the mean content of fat in the femur marrow of roe deer and red deer killed by lynx in BPF in 1991-1996.

deer and 24 red deer killed by lynx, the physical condition of roe deer was normal and on average higher than that of red deer. Red deer calves had extremely low fat content in autumn-winter (Fig. 2). 
Table 4. Selection of roe deer and red deer by individual male and female lynx in relation to the relative availability of these ungulates in their territories. NOBS - total number of observed deer in the area delimited as minimum convex polygon of all found prey of a given lynx; $N_{\text {KILL }}$ - number of deer found as killed by a given lynx. $D$ - Ivlev's selectivity index (as modified by Jacobs 1974): $D=$ $(r-p) /(r+p-2 r p)$, where $r$ is the fraction of a species among deer killed by lynx, and $p$ is a fraction of a species in the total number of deer. $D$ ranges from 1 (maximum positive selection) to 0 (random choice of prey) to -1 (complete avoidance of prey).

\begin{tabular}{|c|c|c|c|c|c|c|c|c|}
\hline \multirow[t]{2}{*}{ Lynx } & \multirow[t]{2}{*}{ NoBS } & \multicolumn{2}{|c|}{$\begin{array}{c}\text { Proportions of deer } \\
\text { available }\end{array}$} & \multirow[t]{2}{*}{$N_{\text {KILL }}$} & \multicolumn{2}{|c|}{$\begin{array}{l}\text { Proportions of deer } \\
\text { killed }\end{array}$} & \multirow{2}{*}{$\begin{array}{c}D \text { index } \\
\text { for roe } \\
\text { deer }\end{array}$} & \multirow{2}{*}{$\begin{array}{c}D \text { index } \\
\text { for red } \\
\text { deer }\end{array}$} \\
\hline & & Roe deer & Red deer & & Roe deer & Red deer & & \\
\hline \multicolumn{9}{|c|}{ Adult males } \\
\hline Makary & 124 & 0.07 & 0.93 & 8 & 0.50 & 0.50 & 0.85 & -0.85 \\
\hline Trofim & 257 & 0.30 & 0.70 & 19 & 0.58 & 0.42 & 0.53 & -0.53 \\
\hline Iwan & 54 & 0.41 & 0.59 & 8 & 0.87 & 0.13 & 0.82 & -0.82 \\
\hline \multicolumn{9}{|c|}{ Subadult males } \\
\hline Bazyliszek & 179 & 0.24 & 0.76 & 13 & 0.85 & 0.15 & 0.89 & -0.89 \\
\hline Igor & 20 & 0.90 & 0.10 & 8 & 1.00 & 0 & 1 & -1 \\
\hline \multicolumn{9}{|c|}{ Females } \\
\hline Sonia & 99 & 0.09 & 0.91 & 15 & 0.73 & 0.27 & 0.93 & -0.93 \\
\hline Tamara & 110 & 0.12 & 0.88 & 6 & 0.83 & 0.17 & 0.95 & -0.95 \\
\hline Bazyliszek's mother & 176 & 0.21 & 0.79 & 8 & 1.00 & 0 & 1 & -1 \\
\hline Diana & 226 & 0.27 & 0.73 & 11 & 1.00 & 0 & 1 & -1 \\
\hline Natasza & 154 & 0.29 & 0.71 & 7 & 0.71 & 0.29 & 0.72 & -0.72 \\
\hline
\end{tabular}

Table 5. Selection for roe deer and red deer by all lynx in the regions of BPF differing in densities and proportions of deer. Density of deer as censused in March 1991. $N_{\mathrm{KILL}}$ - number of lynx kills found in 1987/88-1996. $D$ - selectivity index (see explanation to Table 4). BNP - Białowieża National Park. ${ }^{a}$ total number of kills includes 8 kills found in two other (not listed) game districts.

\begin{tabular}{|c|c|c|c|c|c|c|c|}
\hline \multirow[t]{2}{*}{ Forest part } & \multicolumn{2}{|c|}{$\begin{array}{l}\text { Density of deer } \\
\left(n / \mathrm{km}^{2}\right)\end{array}$} & \multirow[t]{2}{*}{$N_{\text {KLL }}$} & \multicolumn{2}{|c|}{$\begin{array}{l}\text { Proportions of deer } \\
\text { killed }\end{array}$} & \multirow{2}{*}{$\begin{array}{l}D \text { index } \\
\text { for } \\
\text { roe deer }\end{array}$} & \multirow{2}{*}{$\begin{array}{l}D \text { index } \\
\quad \text { for } \\
\text { red deer }\end{array}$} \\
\hline & Roe deer & Red deer & & Roe deer & Red deer & & \\
\hline Puszcza Ladzka & 19.3 & 4.0 & 9 & 1.00 & 0 & 1 & -1 \\
\hline Browsk & 2.7 & 3.1 & 13 & 0.85 & 0.15 & 0.73 & -0.73 \\
\hline Narewka & 3.3 & 4.8 & 17 & 0.94 & 0.06 & 0.92 & -0.92 \\
\hline Hajnówka & 5.9 & 5.1 & 17 & 0.77 & 0.23 & 0.48 & -0.48 \\
\hline Zwierzyniec & 4.1 & 6.0 & 26 & 0.89 & 0.11 & 0.84 & -0.84 \\
\hline Leśna & 1.9 & 7.2 & 13 & 0.46 & 0.54 & 0.53 & -0.53 \\
\hline Białowieża & 2.4 & 10.4 & 11 & 0.82 & 0.18 & 0.90 & -0.90 \\
\hline Nothern BNP & 3.3 & 8.1 & 12 & 0.33 & 0.67 & 0.10 & -0.10 \\
\hline Southern BNP & 3.1 & 16.2 & 18 & 0.39 & 0.61 & 0.53 & -0.53 \\
\hline Whole Białowieża Forest & 4.9 & 6.1 & $144^{\mathrm{a}}$ & 0.74 & 0.26 & 0.56 & -0.56 \\
\hline
\end{tabular}



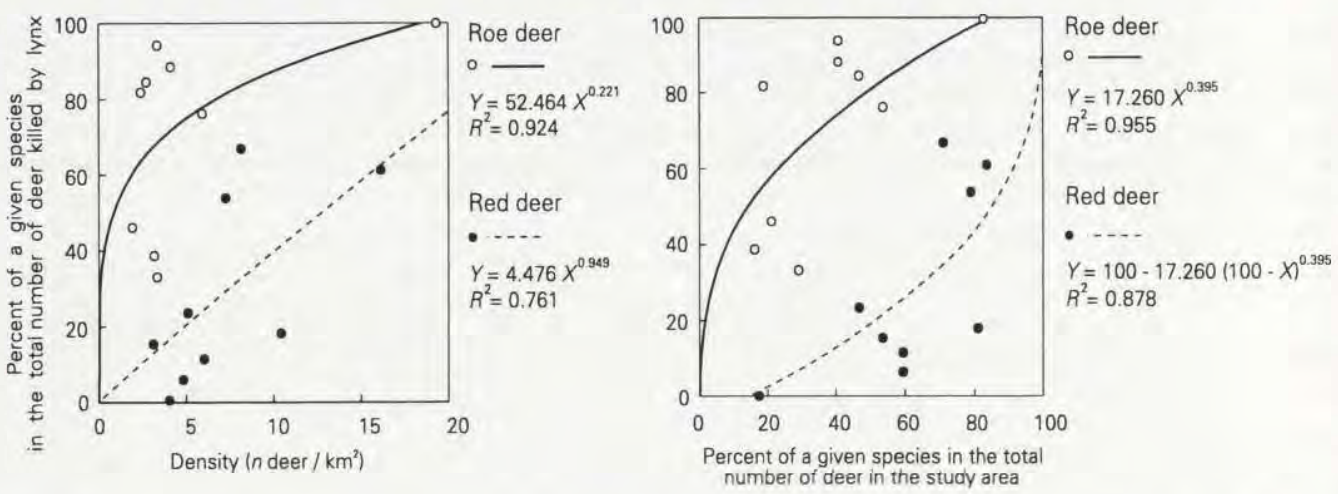

Fig. 3. Functional (dietary) responses by lynx to spatially varying densities of roe deer and red deer (upper panel) and the percentages of each species in the total number of deer (lower panel). Each point denotes one part of BPF (game hunting district in the exploited forests or part of BNP, covering from 20 to $75 \mathrm{~km}^{2}$, see Jędrzejewska et al. 1994), where both ungulates were surveyed and sufficient number of lynx kills were found (see Table 5 for further details). Regression lines were forced through points $\langle 0,0\rangle$ (upper panel) and $\langle 0,0\rangle,\langle 100,100\rangle$ (lower panel).

Lynx selection for roe deer was clear not only in the pooled data (Ivlev's selectivity index $D=0.56$ ), but also when analysed against the spatial variation in prey densities and relative abundance in various parts of BPF. In 10 lynx home ranges we compared the proportions of roe deer among ungulate prey found to the proportions of roe deer in the total number of deer observed by us in 1991-1995. In various home ranges the share of roe deer available varied from 7 to $90 \%$, and the percentage of this species among deer killed by lynxes varied from 50 to $100 \%$ (Table 4). Ivlev's selectivity indices (after Jacobs 1974) were calculated for individual lynxes; they were lowest in adult males and markedly higher in subadult males and all females $\left(U_{\mathrm{s}}=19, p=0.05\right.$, Mann-Whitney $U$-test). This showed that the higher proportion of roe deer relative to red deer among prey of female lynx and subadults (already shown in Table 2) actually resulted from their higher selectivity for this small ungulate.

Data on all age/sex groups of lynx were fairly uniformly collected over most of the Polish part of BPF. This enabled us to analyse the dietary responses of the lynx to spatially varying densities and relative abundance of roe and red deer (Table 5). We defined this as a functional response of lynx, but it must be noted that it concerns lynx response to spatial, and not temporal, changes in deer abundance. The functional response for roe deer densities resembled a type II

Fig. 4. Sequences of killing and utilisation of prey by radiocollared lynx. Lengths of bars denote the time of lynx utilisation of a given prey. Parallel bars are two kills located close to each other and utilised concurrently. In such cases, consumption time of each prey (plotted in Fig. 6) was 1/2 the total time spent at the two kills. Lengths of lines mark the time of searching and hunting for ungulates (possibly, some small-sized prey could had been captured during that time). 
Adult females with young

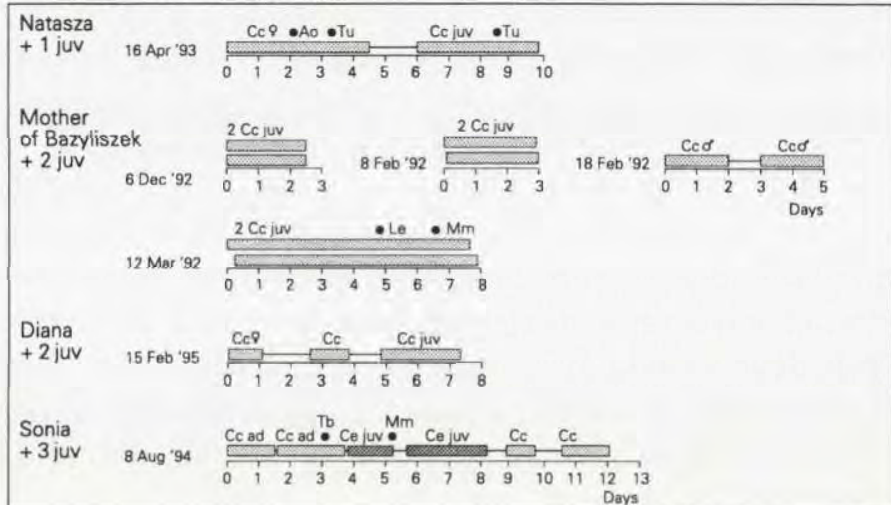

\section{Adult males}

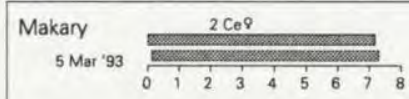

Iwan

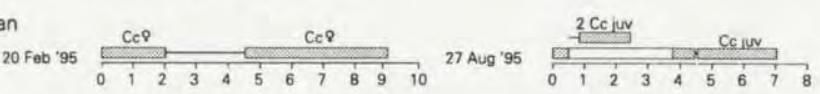

Trofim 21 Mar'95 Cod Cejur Cc9

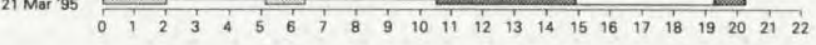

13 May'95 Ces

4 Jun'95 \begin{tabular}{l} 
Ced \\
\hline
\end{tabular}

Ungulate prey fed upon:

$\square$ Cc - Capreolus capreolus

- $\mathrm{Ce}$ - Cervus elaphus

$\square$ kill temporarily abandoned

Subadult males and females

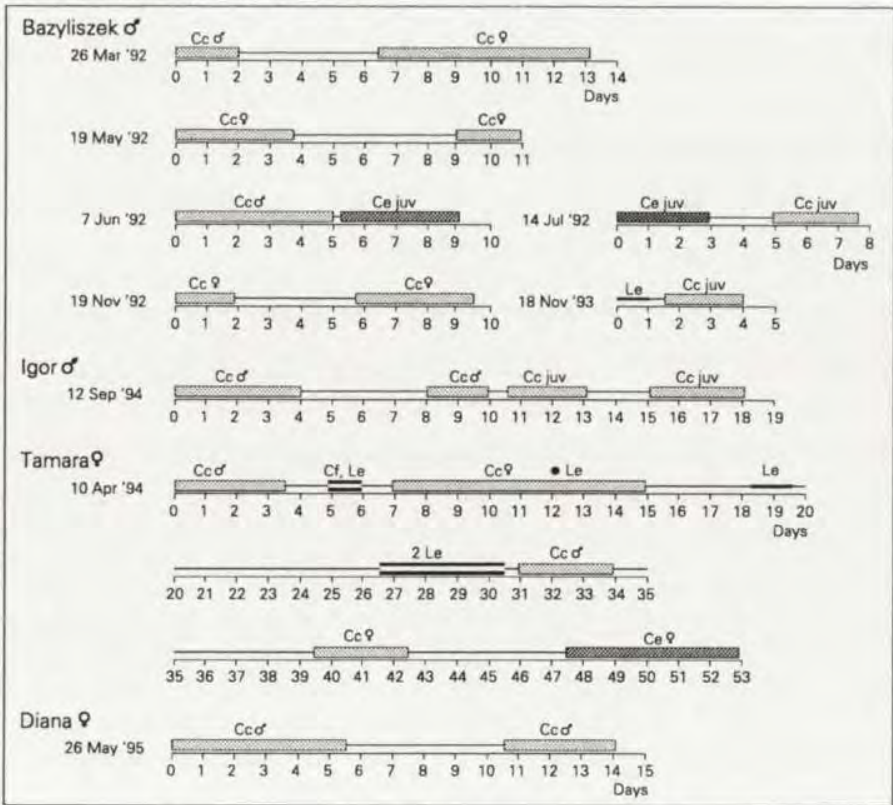

- consumption time estimated

- consumption time unknown

Le - Lepus europaeus

Tb - Tetrastes bonasia

Cf - Canis familiaris

Ao - Asio otus

Tu - Turdus sp.

- searching time 
(asymptotic curve), indicating a fast increase in roe deer percentage taken by lynx with increasing roe deer densities (Fig. 3). In contrast, the share of red deer among lynx prey grew in a nearly linear manner with increasing densities of deer (type I functional response). Mathematically, exponential equations (with exponents $<1$ ) described the lines of best fit to empirical points (Fig. 3). The relative proportions of both ungulate species were more important than their absolute numbers for the selection of particular species by lynx. In these data, it appeared that the share of roe deer among lynx ungulate prey grew very fast with increasing proportion of this species among all deer. In contrast, the share of red deer in lynx prey killed increased only when this species heavily outnumbered the roe deer (Table 5, Fig. 3).

\section{Killing rates and prey utilisation by lynx}

The temporal pattern of killing and utilisation of prey by lynx is shown in Fig. 4. Generally, all lynx exhibited similar foraging behaviour (killing - feeding on a carcass and staying near it for some days - leaving it to search and hunt for another one - killing, and so on), but there were notable differences among sex/age classes. Family groups (females with kittens) consumed deer within a short time, and in 3 of 19 cases, they utilised two prey at a time, both killed by a female within a short time frame and spatial distance (Fig. 4). Moreover, females (and occasionally kittens, too) killed small animals (hare, hazel hens) while still feeding on an ungulate carcass. The rates of killing and consumption of prey by females with kittens clearly reflected the food demands of growing juveniles. Adult male lynx behaved as if necessity to stay in one place (to feed on a carcass) conflicted with the need to move around. In 4 out of 18 cases, males utilised two kills at a time, but in only one case was it actually two prey killed near each other (Fig. 4). In other cases, adult males typically left a prey before it was consumed, roamed

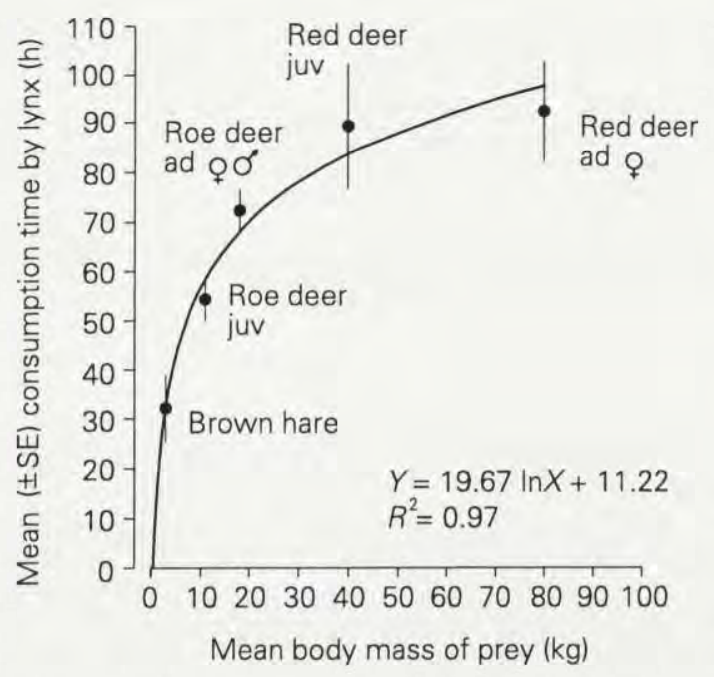

Fig. 5. Mean ( \pm SE) consumption times by lynx in relation to the mean body mass of prey. Data on body masses after Dzięciołowski (1969), Miłkowski (1970), and Cabon-Raczyńska (1974). 
far away, killed another prey at a distant place, and after feeding on it for a few days, returned to the previous kill to finish it. Subadults were evidently least effective in their hunting for ungulates. They stayed longer at each kill and utilised it as completely as possible. They never managed to have two kills at a time, and their searching times were long and interspersed with catches of smaller prey, usually hare but also items as strange as domestic dog.

The time a lynx spent feeding on a kill was estimated reliably for 101 ungulates and 5 hares; it varied from $8 \mathrm{~h}$ to 8 days ( $192 \mathrm{~h}$ ), depending on the size of prey, the size, age and number of lynxes feeding on it, and casual factors (eg disturbance by scavengers). Generally, consumption time by lynx grew logarithmically with prey size, from an average of $32 \mathrm{~h}$ (1.3 days) for a brown hare to $92 \mathrm{~h}$ (3.8 days) for a female red deer (Fig. 5). Roe deer were eaten within 3 days, and a red deer took 25\% longer. An ungulate prey (roe and red deer pooled) was fed upon for 76 $\pm 38 \mathrm{~h}$ (mean $\pm \mathrm{SD}$ ), ie 3.2 days, during which the lynx usually stayed within a few meters to several hundred meters of the kill and fed at least twice daily.

In the majority of killed roe deer $(80 \%, n=78)$, the lynx utilised nearly all edible tissue (consumption $>75 \%$ ); $19 \%$ carcasses were classified as half-eaten (25-75\% of tissue consumed). Lynx abandoned one kill (1\%) after having consumed only a small portion $(<25 \%)$. Roe deer carcass was utilised in $93 \pm 17 \%$ (mean \pm SD) and all age/sex classes of lynx utilised their kills as completely as possible (on average $94 \%$ by adult males, $96 \%$ by adult females with kittens, and $90 \%$ by subadults). The red deer, a notably larger prey, was consumed completely in $36 \%$
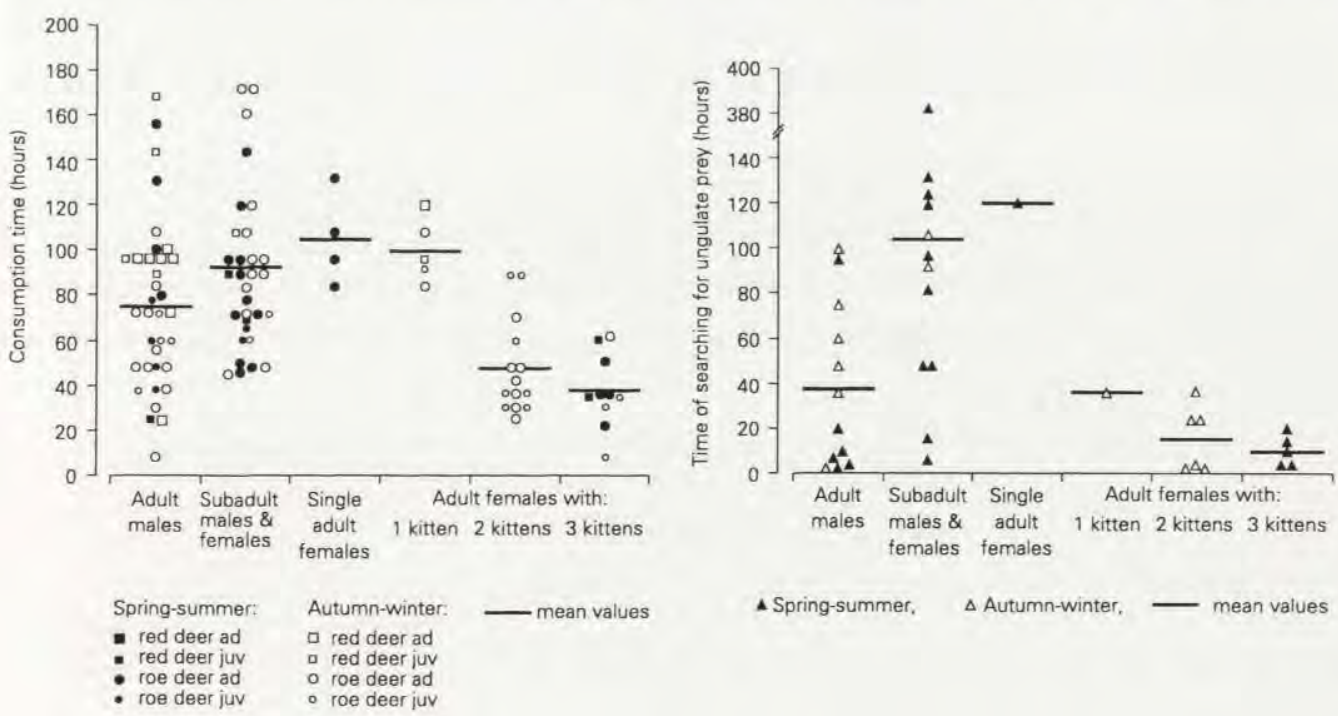

Fig. 6. Left panel: Consumption times of ungulate prey by lynx of various age, sex and reproductive status. Each point denotes the time a lynx stayed at and fed upon one prey. Right panel: Iynx searching times for ungulates. Each point denotes the time from leaving the remains of one deer to killing another deer. 
of cases, only ( $n=22) ; 59 \%$ of kills were half-eaten and $5 \%$ abandoned after little consumption. On average, red deer carcass was consumed in $75 \pm 23 \%$. Despite small samples of red deer killed, clear differences in their use by various age/sex classes of lynx emerged. Subadults consumed on average $94 \%$ of all edible tissue of red deer, adult females with kittens $79 \%$, and adult male lynx (often wandering from one kill to another) $67 \%$, only. The causes of uncomplete utilisation could not always be determined, but carcasses were often scavenged by wild boar (frequent in winter, see Jędrzejewski et al. 1993) or they decayed in summer.

Consumption times of ungulate prey varied greatly among age and sex classes of lynx but no consistent seasonal differences (ie spring-summer versus autumn-winter) were found (Fig. 6). Among single lynxes, the time spent at a deer carcass ranged from an average of $75 \pm 37 \mathrm{~h}$ in adult males to $105 \pm 20 \mathrm{~h}$ in single adult females. In family groups (female + kittens), the time spent at a kill declined with increasing number of young; it was as short as $38 \pm 17 \mathrm{~h}$ in a female with 3 kittens (Fig. 6). We calculated the regression equation of mean consumption time of roe deer in relation to the number of kittens in a litter $\left(\log _{10} T_{\mathrm{C}}=2.063-0.1713\right.$ $N_{\text {juv }}, R^{2}=0.93, n=4, p<0.05$ ), which we used for further calculations of predation rates (see below).

In 37 cases, we were able to estimate the time from leaving the remains of one ungulate prey until the lynx killed another one. We called it 'searching time', but during that time a lynx could (and in several cases it did) capture and eat small-sized prey. As defined, searching time ranged from nearly 0 to $383 \mathrm{~h}$ (ie 16 days). In most cases, however, lynx spent $0.5-5$ days hunting for deer after having left the remains of the previous kill. On average, all lynx spent $54 \pm 70 \mathrm{~h}$, ie 2.25 days on searching for the next ungulate prey. Among single lynx, adult males

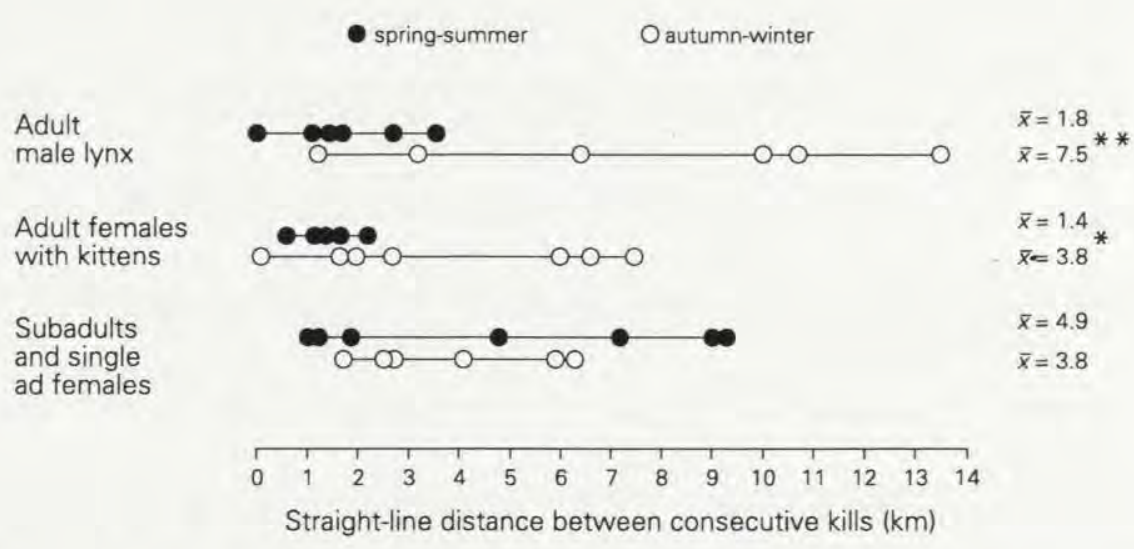

Fig. 7. Straight-line distances between consecutive kills (ungulates only) of lynxes of various age, sex and breeding status. Each point is a distance between two consecutive kills. Differences between seasons: ${ }^{* *} p<0.01,{ }^{*} p=0.05$ (Mann-Whitney $U$-test). 
spent markedly shorter time hunting ( $38 \pm 37 \mathrm{~h}$ ) than subadults of both sexes (104 $\pm 97 \mathrm{~h}$ ). In family groups, where a female had to provide kittens with large amounts of food, searching time was shortest and least variable (Fig. 6). A female with 3 kittens spent, on average, $10 \pm 8 \mathrm{~h}$ from leaving one deer carcass till killing another one. We calculated the regression of mean searching times against the number of kittens in a litter $\left(\log _{10} T \mathrm{~S}=1.999-0.36445 N_{\mathrm{juv}}, R^{2}=0.96, n=4, p<0.05\right)$ and used it for estimating predation rates (see below).

Of 37 straight-line distances between consecutively killed deer, nearly half (49\%) were within 1-3 km, but distances as far as $10-13.5 \mathrm{~km}$ were also recorded (Fig. 7). Consecutively killed deer were found $4.0 \pm 3.4 \mathrm{~km}$ (mean $\pm \mathrm{SD}$ ) apart. In this aspect of lynx predation, there were clear seasonal shifts in adult males and females with kittens (Fig. 7). In adult females, which in spring and summer have to bring along their small kittens to each new kill, the distances between consecutive kills were shortest and least variable $(1.4 \pm 0.6 \mathrm{~km})$. In autumn-winter, when young are bigger, more mobile, and often assist their mothers in hunting, the mean distance increased to $3.8 \pm 2.9 \mathrm{~km}$. Consecutive prey of adult male lynx were, on average, $1.8 \pm 1.2 \mathrm{~km}$ apart in spring-summer, but $7.5 \pm 4.7 \mathrm{~km}$ apart in winter, when males spent much time walking in search for females and markedly expanded their home ranges (Schmidt et al., in print). Spatially concentrated kills of adult lynx in spring-summer were obviously facilitated by the seasonal abundance and low mobility of juvenile deer, but it may have resulted from the hunting efficiency of adult lynx as well. In the subadults, especially in

Table 6. Killing rates by lynx of various sex/age classes on roe deer and red deer in BPF in 1991-1996. Five variants of family size (female with kittens) cover the whole range of observed individual variation (females with 1,2 , or 3 juveniles) and year-to-year variation in the mean breeding success of lynx population during the study period (see Table 7). Ratios of roe deer to red deer killed from Table 2. Searching and consumption times of deer - data points in Fig. 6. In the case of females with young, the values were read from regression line of mean searching time and consumption time of roe deer in relation to the number of kittens in a litter (see Fig. 6 for data and text for regression equations). Due to the small sample of empirical data on consumption time of red deer by female lynx with young, these values were calculated by multiplying the consumption time of roe deer by 1.256 (ie an average ratio for the whole material). M - male, F - female, ad - adult.

\begin{tabular}{|c|c|c|c|c|c|c|c|c|}
\hline \multirow{2}{*}{ Parameter } & \multirow[t]{2}{*}{ Ad M } & \multirow{2}{*}{$\begin{array}{c}\text { Subadults } \\
\text { and single } \\
\text { ad F }\end{array}$} & \multicolumn{5}{|c|}{$\begin{array}{l}\text { Adult } \mathrm{F} \text { with the following number } \\
\text { of kittens: }\end{array}$} & \multirow{2}{*}{$\begin{array}{c}\text { Mean } \\
\text { for all } \\
\text { lynx }\end{array}$} \\
\hline & & & 1.0 & 1.4 & 1.8 & 2.0 & 3.0 & \\
\hline Roe : red deer ratio & 1.64 & 8.50 & 3.40 & 3.40 & 3.40 & 3.40 & 3.40 & 2.80 \\
\hline Searching time $(\mathrm{h})$ & 37.7 & 105.4 & 43.1 & 30.8 & 22.0 & 18.6 & 8.1 & 54.0 \\
\hline Consumption time of roe deer $(\mathrm{h})$ & 66.5 & 93.3 & 77.9 & 66.5 & 56.8 & 52.5 & 35.4 & 72.2 \\
\hline$n$ roe deer killed/month & 3.9 & 3.2 & 4.4 & 5.5 & 6.8 & 7.5 & 12.2 & 4.0 \\
\hline Consumption time of red deer $(\mathrm{h})$ & 91.9 & 100.0 & 97.8 & 83.5 & 71.3 & 65.9 & 44.5 & 90.7 \\
\hline$n$ red deer killed/month & 2.4 & 0.4 & 1.3 & 1.6 & 2.0 & 2.2 & 3.6 & 1.5 \\
\hline Total $n$ deer killed/month & 6.3 & 3.6 & 5.7 & 7.1 & 8.8 & 9.7 & 15.8 & 5.5 \\
\hline Mean kill rate ( $n$ days/deer) & 4.7 & 8.3 & 5.2 & 4.2 & 3.4 & 3.1 & 1.9 & 5.4 \\
\hline
\end{tabular}


Table 7. Predation impact by lynx on populations of roe and red deer in Białowieża Primeval Forest in 1991-1996. See the text for sources of data on lynx and deer population numbers and structure, and methods of calculating predation.

\begin{tabular}{|c|c|c|c|c|c|}
\hline \multirow{2}{*}{ Parameter } & \multicolumn{4}{|c|}{ Years } & \multirow{2}{*}{ Mean (SD) } \\
\hline & $1991 / 92$ & $1992 / 93$ & $1993 / 94$ & $1995 / 96$ & \\
\hline \multicolumn{6}{|c|}{ Lynx population } \\
\hline Density of adult lynx $\left(n / 100 \mathrm{~km}^{2}\right)$ & 2.8 & 3.2 & 3.2 & 2.4 & $2.9(0.4)$ \\
\hline including: ad males & 1.26 & 1.57 & 1.25 & 1.01 & $1.27(0.2)$ \\
\hline reproducing ad females & 0.98 & 1.15 & 1.09 & 0.60 & $0.96(0.2)$ \\
\hline subadults and single ad females & 0.56 & 0.48 & 0.86 & 0.79 & $0.67(0.2)$ \\
\hline Density of kittens $\left(n / 100 \mathrm{~km}^{2}\right)$ & 2.3 & 1.7 & 2.0 & 0.6 & $1.65(0.7)$ \\
\hline Mean number of kittens per mother & 2.0 & 1.4 & 1.8 & 1.0 & $1.6(0.4)$ \\
\hline \multicolumn{6}{|c|}{$\begin{array}{c}\text { Roe deer Capreolus capreolus } \\
\text { Population dynamics }\end{array}$} \\
\hline Density in March $\left(n / 100 \mathrm{~km}^{2}\right)$ & 492 & 425 & 288 & 324 & $382(93)$ \\
\hline Percentage of adult females & 46 & 45 & 51 & 41 & $46 \quad(4)$ \\
\hline$n$ juv/adult female in spring & 1.45 & 1.45 & 1.45 & 1.45 & 1.45 \\
\hline Juveniles born in spring $\left(n / 100 \mathrm{~km}^{2}\right)$ & 328 & 277 & 213 & 193 & $253(62)$ \\
\hline Density in May/June $\left(n / 100 \mathrm{~km}^{2}\right)$ & 820 & 702 & 501 & 517 & $635(153)$ \\
\hline Year-to-year mortality $\left(n / 100 \mathrm{~km}^{2}\right)$ & 395 & 414 & $?$ & $?$ & $?$ \\
\hline \multicolumn{6}{|c|}{ Lynx predation } \\
\hline Total yearly predation $\left(n / 100 \mathrm{~km}^{2}\right)$ & 169 & 169 & 181 & 110 & $157(32)$ \\
\hline Predation as percentage of: & & & & & \\
\hline spring/summer density of roe deer & 21 & 24 & 36 & 21 & $26 \quad(7)$ \\
\hline roe deer increase due to breeding & 52 & 61 & 85 & 57 & $64 \quad(15)$ \\
\hline annual mortality of roe deer & 43 & 41 & $?$ & $?$ & $?$ \\
\hline \multicolumn{6}{|c|}{ Hunting harvest } \\
\hline Annual hunting harvest $\left(n / 100 \mathrm{~km}^{2}\right)$ & 85 & 114 & 102 & 86 & 97 (14) \\
\hline $\begin{array}{l}\text { Hunting harvest as percentage of: } \\
\text { spring/summer density of roe deer }\end{array}$ & & & & & \\
\hline roe deer increase due to breeding & $\begin{array}{l}10 \\
26\end{array}$ & $\begin{array}{l}16 \\
41\end{array}$ & $\begin{array}{l}20 \\
48\end{array}$ & 45 & $\begin{array}{rr}16 & (4) \\
40 & (10)\end{array}$ \\
\hline annual mortality of roe deer & 22 & 28 & $?$ & $?$ & $?$ \\
\hline \multicolumn{6}{|c|}{$\begin{array}{l}\text { Red deer Cervus elaphus } \\
\text { Population dynamics }\end{array}$} \\
\hline Density in March $\left(n / 100 \mathrm{~km}^{2}\right)$ & 607 & 416 & 359 & 463 & $461(106)$ \\
\hline Percentage of adult females & 46 & 44 & 48 & 47 & $46 \quad(2)$ \\
\hline$n$ juv/adult female in spring & 0.9 & 0.9 & 0.9 & 0.9 & 0.9 \\
\hline Juveniles born in spring $\left(n / 100 \mathrm{~km}^{2}\right)$ & 251 & 165 & 155 & 196 & 192 (43) \\
\hline Density in May/June $\left(n / 100 \mathrm{~km}^{2}\right)$ & 858 & 581 & 514 & 659 & $653(149)$ \\
\hline Year-to-year mortality $\left(n / 100 \mathrm{~km}^{2}\right)$ & 442 & 222 & $?$ & $?$ & $?$ \\
\hline \multicolumn{6}{|c|}{ Lynx predation } \\
\hline Total yearly predation $\left(n / 100 \mathrm{~km}^{2}\right)$ & 65 & 70 & 66 & 42 & 61 (13) \\
\hline \multicolumn{6}{|l|}{ Predation as percentage of: } \\
\hline spring/summer density of red deer & $\begin{array}{r}8 \\
26\end{array}$ & $\begin{array}{l}12 \\
42\end{array}$ & $\begin{array}{l}13 \\
43\end{array}$ & $\begin{array}{r}6 \\
21\end{array}$ & $\begin{array}{ll}10 & (3) \\
32 & (11)\end{array}$ \\
\hline annual mortality of red deer & $\begin{array}{l}26 \\
15\end{array}$ & 32 & $?$ & $\begin{array}{l}21 \\
?\end{array}$ & ? \\
\hline \multicolumn{6}{|c|}{ Hunting harvest } \\
\hline Annual hunting harvest $\left(n / 100 \mathrm{~km}^{2}\right)$ & 133 & 131 & 131 & 140 & 134 \\
\hline Hunting harvest as percentage of: & & & & & \\
\hline spring/summer density of red deer & 16 & 23 & $\begin{array}{l}25 \\
85\end{array}$ & 21 & $21 \quad(4)$ \\
\hline $\begin{array}{l}\text { red deer increase due to breeding } \\
\text { annual mortality of red deer }\end{array}$ & $\begin{array}{l}53 \\
30\end{array}$ & $\begin{array}{l}79 \\
59\end{array}$ & $\begin{array}{l}85 \\
?\end{array}$ & $?$ & $\begin{array}{ll}72 & (14) \\
?\end{array}$ \\
\hline annual mortality of red deer & & & & & ? \\
\hline
\end{tabular}


spring-summer (the first season of their independent lives), the straight-line distances between consecutively killed deer were longer than those in adult males and females with young (Fig. 7). In the latter case (subadults vs adult females with kittens), the difference was statistically significant $\left(U_{\mathrm{S}}=26.5, p<0.05\right.$, Mann-Whitney $U$-test).

Based on the mean proportions of roe deer and red deer among prey killed, the mean consumption and searching times, we calculated the killing rates by three groups of lynx: (1) adult males, (2) subadults and single adult females, and (3) females with kittens. In this last case, five variants of litter size were used to cover both individual variation in family size and between-year variation in the mean values for the lynx population (Table 6). A subadult lynx or a non-breeding adult female killed, on average, 3.6 deer/month ( 43 deer/year), most of them being roe deer (Table 6). An adult male lynx harvested 6.3 deer/month ( 76 deer annually). Killing rates of females leading kittens increased exponentially from 5.7 deer/month (69 per year) in a female with one young to 15.8 deer/month (190 per year) in a female with 3 young. The average kill rate by lynx was 1 deer/5.4 days (Table 6).

We calculated mean daily food intake by adult males, family groups, and subadult lynx, based on proportions of red deer, roe deer and brown hare among their kills, mean percentage of ungulate prey utilisation, and the assumption that consumable fraction of an ungulate constitutes $75 \%$ of its body mass (after Messier and Crete 1985). On average, one lynx consumed about $2 \mathrm{~kg}$ crude biomass of food daily (adult male $3.6 \mathrm{~kg}$, subadult $1.7 \mathrm{~kg}$, family groups, ie females with 1-3 kittens, $1.6-2.2 \mathrm{~kg}$ per capita).

\section{Predation impact by lynx population on roe deer and red deer}

We calculated the total impact of lynx predation on deer based on: (1) densities of lynx, (2) lynx killing rates, and (3) densities of roe and red deer. In 1991-1996, the winter density of adult lynx was little variable $\left(2.4-3.2\right.$ inds $/ 100 \mathrm{~km}^{2}, \mathrm{CV}=$ $13 \%$ ), but the reproduction rates of lynx population varied from 0.25 juv/adult in $1995 / 96$ to 0.67 juv/adult in $1991 / 92$, and the mean litter size from 1 to 2 , respectively (Table 7). In consequence, from 0.6 to 2.3 kittens $/ 100 \mathrm{~km}^{2}$ were recorded in addition to adult and subadult lynx $(\mathrm{CV}=45 \%)$. Total numbers of lynx were fairly stable in 1991-1994, and by $40 \%$ lower in 1995/96.

Annually, population of lynx took from 110 to 181 roe deer from an average $100 \mathrm{~km}^{2}$, that is $21-36 \%$ (mean $26 \%$ ) of the spring (seasonally highest) numbers of roe deer (Table 7). Predation was very high (52-85\%, mean $64 \%$ ), as compared to the roe deer annual increase due to reproduction. Lynx predation was the single most important factor of roe deer mortality, far exceeding the roles of hunting harvest $(27 \%)$ and other factors such as wolf predation, poaching, disease, and other (Fig. 8). Lynx population killed $42-70$ red deer from $100 \mathrm{~km}^{2}$ per year, which constituted $6-13 \%$ (mean $10 \%$ ) of spring numbers of deer and $21-43 \%$ (mean $33 \%$ ) 


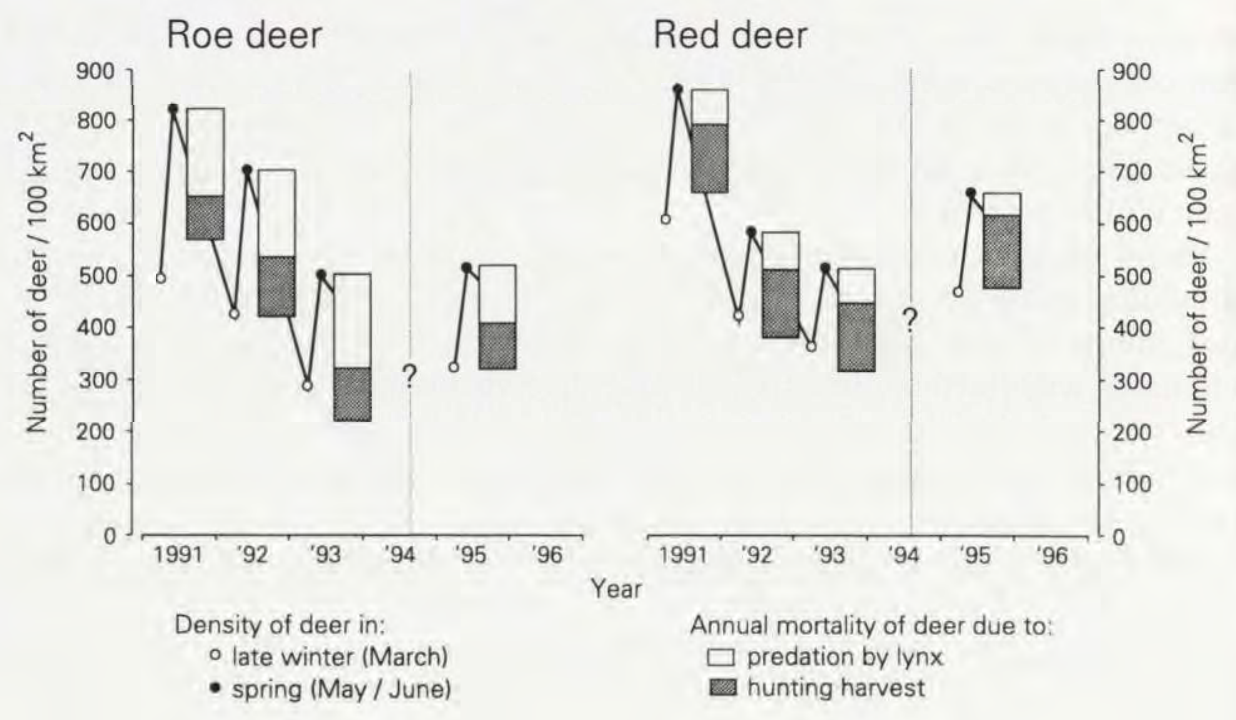

Fig. 8. Total annual predation by lynx population and annual hunting harvest compared to the mean densities of roe deer in BPF in 1991-1995/96. Late winter (March) densities of deer were surveyed by drive censuses; spring (May/June) densities were calculated based on proportions of adult females in the populations in late winter and average number of juveniles per adult female in spring (see Table 7 for further explanations). A vertical line separates results of ungulate censuses obtained by somewhat different methods (see Material and methods for details).

of their annual increase due to reproduction (Table 7). Predation by lynx was less important factor of red deer mortality than hunting harvest (the latter about $45 \%$ ) (Fig. 8). In terms of crude biomass, lynx population harvested $24 \%$ of roe deer population and $6 \%$ of red deer population (both compared to spring-summer standing crop of biomass).

Adult female lynx with kittens were responsible for an average of $44 \%$ (range $29-52 \%$ ) of the total lynx predation on roe deer. Adult male lynx contributed $39 \%$ (from 33 to $44 \%$ ) and subadults, on average, $17 \%$ (range $11-31 \%$ ). For red deer, adult male lynx accounted for 55 to $69 \%$ (mean $61 \%$ ) of all red deer killed. Adult females with kittens contributed, on average, $34 \%$ (range $22-40 \%$ ) and subadults $5 \%$ (range $3-9 \%$ ).

During the study period, roe and red deer populations declined markedly, mainly due to deliberate reduction of 'excess' game by forestry personnel. The decline exceeded recruitment by about 60 red deer and 45 roe deer per $100 \mathrm{~km}^{2}$ annually (Fig. 8). These numbers roughly approximated the increase in hunting harvest in 1991-1995 as compared to 1985-1990, when from 40 to 81 (mean 62) red deer and from 26 to 52 (mean 41 ) roe deer per $100 \mathrm{~km}^{2}$ had been harvested annually (compare Okarma et al. 1995). 


\section{Discussion}

In the review of lynx feeding habits and prey selection in the Palearctic region (Jędrzejewski et al. 1993), we have shown that south of $55^{\circ} \mathrm{N}$ the lynx feeds primarily on ungulates and strongly selects the smallest species available: the roe deer, the chamois Rupicapra rupicapra and the musk deer Moschus moschiferus. But the body masses of these smallest Palearctic ungulates far exceed the daily food requirements of wild lynx, which is about $2 \mathrm{~kg}$ of meat (Haglund 1966, this paper). Therefore, lynx feeding strategy is to kill a prey and secure it (by hiding against scavengers and other disturbance) for utilisation during few to several days. Nonetheless, portions of killed prey are always wasted, and the actual lynx predation is definitely higher than expected from its daily food requirements. The direct recording of lynx hunting and feeding done by us in Białowieża Primeval Forest has shown that the true kill rate was about two times higher (67 deer/year by one lynx) than expected from daily food consumption of lynx (30-40 deer/year).

In BPF, a lynx killed a deer every 5.4 days, on average. Similar results ( 5 days) were obtained by Breitenmoser and Haller (1993), who radiotracked lynx in 1983-1988 in the population reintroduced to the Swiss Alps. There, the main prey of lynx was roe deer and chamois. Markedly higher kill rates (one ungulate every 2.7 days) was found in a female with 2 kittens (Breitenmoser and Haller 1987), which is very close to the respective data from our study ( 3.1 days in a female with 2 kittens).

In our study it was possible to show the pattern of lynx predation on ungulates and the mechanisms of its variation. Basic components were: (1) densities of lynx population and its reproduction rate, (2) strong positive selection of roe deer, and (3) kill rates depending on sex, age, and breeding status of the lynx. The magnitude of lynx predation on deer is shaped primarily by the density of lynx and its reproduction rate. The density of adult lynx recorded by us $\left(2.4-3.2\right.$ inds $\left./ 100 \mathrm{~km}^{2}\right)$ was about 3 times higher than that reported by Breitenmoser et al. (1993) in a stabilised reintroduced population in the Swiss Jura Mountains. Still, however, it was only about half of the highest recorded lynx densities in Białowieża Forest (over 6 inds $/ 100 \mathrm{~km}^{2}$ in the $1950 \mathrm{~s}$, Jędrzejewski et al. 1996).

In the lynx population, reproduction may vary from, theoretically, complete breeding failure to 3 juveniles in each litter. Such a range of variation at the densities of 2.9 adult lynx $/ 100 \mathrm{~km}^{2}$ (ie the mean observed in our study) would result in the following magnitudes of annual predation: 167 deer $/ 100 \mathrm{~km}^{2}$ when there are no juveniles, 191 deer when each adult female leads one kitten, 237 deer at 2 juv/adult female, and 307 deer at 3 kittens/adult female. In 1991-1995, the actual range of variation was from 1 to 2 juv/mother. The increase of predation rates with growing litter size demonstrates the high demands that the breeding females have to cope with. Their hunting rates grow exponentially as litter size increases (Table 6). Futhermore, during the first months of rearing young, the distances between consecutive kills must be short enough for young to follow the 
mother. It all shows cogently that reproductive success of lynx is critically dependent upon high and localised deer densities.

Our study began in 1991, in the same year when forestry personnel started intense reduction of red and roe deer. Thus, it must be kept in mind that we followed the changes in predation on populations of prey that declined due to an additive effect of human exploitation. Annual hunting harvest was lower than lynx predation but it had a very strong effect on deer population. Hunting season for roe deer lasts from May through February (in May-September only bucks are harvested, and in October-February, females and fawns are shot). Red deer are hunted from August through February. Therefore, most of harvested deer are shot in autumn and winter. In the cold season, lynx cannot lower their predation, which is already 'programmed' by the existing density of lynx and the number of their half-grown young. During our study, lynx population adjusted to lower densities of deer with notable delay. Although proper analysis of lynx numerical response would be possible in longer series of data, it is clear already from our 4-year study, that after a fast, nearly 2-fold decline of roe deer population from 1991 to 1993, it was only in 1995 (and possibly also in 1994 for which data were not available), that the numbers of adult and juvenile lynx decreased. In effect, the percentage predation was highest at the declining population of roe deer. Also, the functional response of lynx to variation in roe deer density as well as in its percentage share in potential prey was close to the asymptotic curve (type II according to Holling 1959). This suggests fairly stable predation impact by lynx at a wide range of densities (except very low ones) of roe deer and inversely density-dependent percentage predation.

The red deer was the most important alternative prey to lynx, but due to its large size it was available mainly to adult male lynx. In subadult lynx, the brown hare was a buffer prey, probably crucial for their survival during the first year of independence. Functional response of lynx to variation in red deer density was linear (type I according to Holling 1959), which suggests constant percentage predation over the entire range of red deer densities. However, the most important influence on the magnitude of lynx predation on red deer was the density of adult male lynx, and this was the least variable component (CV 18\%) of lynx population from year to year. This means, that the ratio of $n$ lynx/100 red deer was growing with the declining numbers of deer. In consequence, lynx percentage predation on red deer was also inversely density-dependent, but it grew with declining density of deer at much slower rate than in the case of lynx predation on roe deer.

The analysis of mechanisms and patterns of lynx predation on roe and red deer allows us to conclude that lynx may lower the numbers of deer but they do not regulate deer population trends (sensu Sinclair 1989). Finally, although this study is the first direct investigation of lynx predation in relation to known numbers of ungulates, our estimates of predation correspond well to the earlier indirect evidence obtained by our review of over dozen studies done in nature reserves and national parks of central and eastern Europe and the former Soviet Union 
(Jędrzejewski et al. 1993). These studies, based on long-term recording of ungulate carcasses with known causes of death, show that the lynx contributed, on average, $40 \%$ to the total natural (ie not caused by humans) mortality of roe deer and about $10 \%$ in red deer. Thus, in the temperate forests of Europe, lynx predation is an important limiting factor of roe deer numbers.

Acknowledgements: We are grateful to S. Śnieżko, K. Zub, E. Bujko, students of Farnborough College of Technology (England), and numerous other person for their help in radiotracking of lynx and search for the remains of their kills, and to the Regional Headquarters of State Forests in Białystok, and the Forest Administration offices of Białowieża, Browsk and Hajnówka for information on deer hunting quotas. We thank K. Zub for drawing the figures and L. Szymura for her help with computer data files. This study was financed by the grant KBN $6 \mathrm{P} 20503405$.

\section{References}

Breitenmoser U. and Haller H. 1987. Zur Nahrungsökologie des Luchses Lynx lynx in den schweizerischen Nordalpen. Zeitschrift für Säugetierkunde 52: 168-191.

Breitenmoser U. and Haller H. 1993. Patterns of predation by reintroduced European lynx in the Swiss Alps. Journal of Wildlife Management 57: 135-144.

Breitenmoser U., Kaczensky P., Dotterer M., Breintenmoser-Wursten C., Capt S., Bernhart F. and Liberek M. 1993. Spatial organization and recruitment of lynx (Lynx lynx) in a re-introduced population in the Swiss Jura Mountains. Journal of Zoology, London 231: 449-464.

Caboń-Raczyńska K. 1974. Variability of the body weight of European hares. Acta Theriologica 19: 69-80.

Dzięciołowski R. 1969. [Weight of our lowland red deer]. Łowiec Polski 19: 4. [In Polish]

Faliński J. B. 1986. Vegetation dynamics in temperate lowland primeval forest. Dr W. Junk Publishers, Dordrecht: 1-537.

Gaross V. Ya. 1979. [Impact of lynx and wolves on the Latvian population of roe deer]. [In: Ecological fundamentals of protection and rational utilisation of predatory mammals. V. E. Sokolov, ed]. Izdatelstvo Nauka, Moskva: 257-261. [In Russian]

Haglund B. 1966. Winter habits of the lynx (Lynx lynx L.) and wolverine (Gulo gulo L.) as revealed by tracking in the snow. Viltrevy 4: 81-310.

Hazzard L. K. 1958. A review of literature on big game census methods. Colorado Game and Fish Department: 1-76.

Holling C. S. 1959. The components of predation as revealed by a study of small-mammal predation of the European pine sawfly. The Canadian Entomologist 91: 293-320.

Jacobs J. 1974. Quantitative measurements of food selection; a modification of the forage ratio and Ivlev's Electivity index. Oecologia (Berlin) 14: 413-417.

Jędrzejewska B., Okarma H., Jędrzejewski W. and Miłkowski L. 1994. Effects of exploitation and protection on forest structure, ungulate density and wolf predation in Białowieża Primeval Forest, Poland. Journal of Applied Ecology 31: 664-676.

Jędrzejewska B., Jędrzejewski W., Bunevich A. N., Miłkowski L. and Okarma H. 1996. Population dynamics of wolves Canis lupus in Białowieża Primeval Forest (Poland and Belarus) in relation to hunting by humans, 1847-1993. Mammal Review 26: 103-126.

Jędrzejewski W., Schmidt K., Miłkowski L., Jędrzejewska B. and Okarma H. 1993. Foraging by lynx and its role in ungulate mortality: the local (Białowieża Forest) and the Palaearctic viewpoints. Acta Theriologica 38: 385-403.

Jędrzejewski W., Jędrzejewska B., Okarma H., Schmidt K., Bunevich A. N. and Miłkowski L. 1996. Population dynamics (1869-1994), demography, and home ranges of the lynx in Białowieża Primeval Forest (Poland and Belarus). Ecography 19: 122-138. 
Kossak S. 1995. Game animal numbers in the Białowieża Forest and proposed ways of game management. Sylwan 139(8): 25-41. [In Polish with English summary]

Lochman J. 1987. [Red deer]. Statni zemedelske nakladatelstvi, Praha: 1-352. [In Czech]

Messier F. 1994. Ungulate population models with predation: a case study with the North American moose. Ecology 75: 478-488.

Messier F. 1995. Trophic interactions in two northern wolf-ungulate systems. Wildlife Research 22: 131-146.

Messier F. and Crete M. 1985. Moose-wolf dynamics and the natural regulation of moose populations. Oecologia (Berlin) 65: 503-512.

Miłkowski L. 1970. [Hunting in Białowieża Primeval Forest. Guide for hunters]. Wydawnictwo Wojewódzki Ośrodek Infomacji Turystycznej, Białystok: 1-71. [In Polish]

Neiland K. A. 1970. Weight of dried marrow as indicator of fat in caribou femurs. Journal of Wildlife Management 34: 904-907.

Okarma H. 1989. Mandible versus long bone marrow fat in red deer. Acta Theriologica 34: 537-544.

Okarma H. 1995. The trophic ecology of wolves and their predatory role in ungulate communities of forest ecosystems in Europe. Acta Theriologica 40: 335-386.

Okarma H., Jędrzejewska B., Jędrzejewski W., Krasiński Z. A. and Miłkowski L. 1995. The roles of predation, snow cover, acorn crop, and man-related factors on ungulate mortality in Białowieża Primeval Forest, Poland. Acta Theriologica 40: 197-217.

Pielowski Z. 1988. [The roe deer]. Państwowe Wydawnictwo Rolnicze i Leśne, Warszawa: 1-293. [In Polish]

Rakov N. V. 1979. [On the role of predators in suppressing the numbers of ungulates in the Amur and Maritime territories]. [In: Ecological fundamentals of protection and rational utilisation of predatory mammals, V. E. Sokolov, ed]. Izdatelstvo Nauka, Moskva: 58-59. [In Russian]

Ratcliffe P. R. 1980. Bone marrow fat as an indicator of condition in roe deer. Acta Theriologica 25 : 333-340.

Sablina T. B. 1955. [Ungulates of Belovezha Primeval Forest]. Trudy Instituta Morfologii Zhivothykh im. A. N. Severtsova, Akademiya Nauk SSSR 15: 1-191. [In Russian]

Schmidt K., Jędrzejewski W. and Okarma H. (in print) Spatial organization and social relations in the Eurasian lynx population in Białowieża Primeval Forest, Poland. Acta Theriologica.

Seip D. R. 1992. Factors limiting woodland caribou populations and their interrelationships with wolves and moose in southeastern British Columbia. Canadian Journal of Zoology 70: 1494-1503.

Sinclair A. R. E. 1989. Population regulation in animals. [In: Ecological concepts: the contribution of ecology to an understanding of the natural world. J. M. Cherrett, ed]. Blackwell Scientific Publications, Oxford: 197-241.

Van Ballenberghe V. and Ballard W. B. 1994. Limitation and regulation of moose populations: the role of predation. Canadian Journal of Zoology 72: 2071-2077.

Zheltukhin A. S. 1986. Biocenotic relationships of the European lynx (Lynx lynx) in the southern taiga of the Upper Volga. Zoologicheskii Zhurnal 65: 259-271. [In Russian with English summary]

Received 28 August 1996, accepted 1 March 1997. 